\title{
Feeding response of Nyctiphanes australis (Euphausiacea) to various nanoplankton sizes and taxa
}

\author{
Graeme J. Haywood*, Carolyn W. Burns \\ Department of Zoology, University of Otago, Box 56, Dunedin, New Zealand
}

\begin{abstract}
Nanoplankton (2 to $20 \mu \mathrm{m})$ are a substantial fraction of the plankton in the sea, where they form a potential food source for zooplankton. Monocultures of 12 nanoplankton taxa of different cell size and 1 species of Thalassiosira (microplankton) were offered to Nyctiphanes australis to determine whether they would be consumed and, if so, determine rates of clearance and ingestion by the euphausiid. $N$. australis ingested very small cells (3.5 to $5.4 \mu \mathrm{m}$ equivalent spherical diameter) at rates $\leq 5 \times 10^{5} \mathrm{cells} \mathrm{h}^{-1}$. A total of 8 nanoplankton taxa were consumed at rates that provided $N$. australis with its minimum food requirement of $2 \%$ body carbon $\mathrm{d}^{-1}$, and so could maintain it when microplankton abundance is low. Our results suggest that $N$. australis can detect and avoid unpalatable food such as the chlorophytes Dunaliella and Nannochloris, but is susceptible to the toxic dinoflagellate Alexandrium minutum.
\end{abstract}

KEY WORDS: Zooplankton $\cdot$ Nanoplankton $\cdot$ Ingestion rate

Resale or republication not permitted without written consent of the publisher

\section{INTRODUCTION}

In his classic book, 'The open sea', Alister Hardy (1956) discussed maritime seasons. In particular, he noted that summer is a period of strong thermocline, diminished nutrients and 'surprisingly few' floating plants. In the waters off Otago, SE New Zealand $\left(170^{\circ} 45^{\prime} \mathrm{E}, 45^{\circ} 45^{\prime} \mathrm{S}\right)$, such a pattern exists between December and February each year (Brewin 1952, Hawke 1989). During this same period, larval and juvenile Nyctiphanes australis are generally abundant along the Otago coast. N. australis provides a key trophic link in the pelagic foodweb between the primary producers (phytoplankton) and many seabirds, fish and mammals.

During the summer of $1997-98,95 \%$ of the potentially available phytoplankton food particles were $<8 \mu \mathrm{m}$ ESD (equivalent spherical diameter) (G. J. Haywood unpubl. data). This observation raises 2 questions concerning the ability of Nyctiphanes australis to utilise this phytoplankton resource: (1) Is Nyctiphanes australis restricted to ingesting phytoplankton $>8 \mu \mathrm{m}$ ESD, thereby leaving the smaller fraction $<8 \mu \mathrm{m}$ ESD because it is too small for $N$. australis to handle? (2) Were the available taxa $<8 \mu \mathrm{m}$ ESD unacceptable to $N$. australis for reasons other than cell size?

The lower size limit for the ingestion of particles by euphausiids is determined by the spacing of setules, the small, hair-like structures on the bristles of the setae on the appendages that form the feeding basket (Jørgensen 1966). For instance, the intersetule distance of Euphausia superba and E. pacifica, which are also filter-feeding euphausiids, is about $7 \mu \mathrm{m}$ (Jørgensen 1966). These species can retain nanoplankton of $5 \mu \mathrm{m}$ diameter (Parsons et al. 1967) and organisms $>10 \mu \mathrm{m}$ with the greatest efficiency (McClatchie \& Boyd 1983).

Intersetule distances on the feeding basket of $\mathrm{NYC}_{\mathrm{C}-}$ tiphanes australis (1 to $7.5 \mu \mathrm{m})$ indicate that nanoplankton can be collected (Dalley 1989). This was confirmed by McClatchie et al. (1991), who offered adult N. australis 2 diatoms, Chaetoceros gracilis and Thalassiosira weissflogii, of diameters 5 and 10 to $15 \mu \mathrm{m}$, 
respectively. C. gracilis was cleared at higher rates than T. weissflogii, but McClatchie et al. (1991) implied that the long siliceous setae may substantially increase the effective size of cells of these species. Long setae may also physically prevent some herbivores like Euphausia superba from eating C. gracilis (Parsons et al. 1967, Opalinski et al. 1997).

Marchant \& Nash (1986), who found large numbers of nanoplanktonic organisms in the gut and faecal material of Euphausia superba, pointed out that relatively little attention has been paid to the grazing of krill on nanoplankton. Taking this into account, our study builds on that of McClatchie et al. (1991). We offered Nyctiphanes australis a range of nanoplanktonic food of diverse size and taxa (including nonsetose nanoplankton) in order to (1) determine which taxa they will eat, (2) establish whether they can eat phytoplankton $<8 \mu \mathrm{m}$, and (3) propose mechanisms to account for any differences in their ingestion rates of the various nanoplankton taxa.

\section{MATERIALS AND METHODS}

Adult Nyctiphanes australis were exposed to 13 species of algae for periods of 2 or $3 \mathrm{~d}$. Monocultures of relatively spherical species of protoctistans (Table 1) in the size range of 2 to $20 \mu \mathrm{m}$ (nanoplankton) were grown in $5 \mathrm{l}$ glass Erlenmeyer flasks in F/2 medium (diatoms) or $\mathrm{F} / 2-\mathrm{Si}$ (flagellates) under a $14: 10 \mathrm{~h}$ light:dark regime and at a constant $16^{\circ} \mathrm{C}$ (Guillard \& Ryther 1962, Guillard 1975). Algal concentrations were measured before and after exposure to euphausiids. There were 10 replicate containers for each algal food that was tested: 7 contained euphausiids, 3 lacked euphausiids (controls).

The dense log phase algal cultures were diluted before use in the feeding experiments. To determine the initial chlorophyll a (chl a) concentration of a culture, $100 \mathrm{ml}$ samples were analysed using the spectrophotometric method of Parsons et al. (1984).

Culture dilutions with sand-filtered seawater were prepared in a clean 801 plastic cask. The water in the cask was stirred continuously while the $5 \mathrm{l}$ aliquots were removed and transferred into each of 10 white plastic pails in random order. This method ensured that the initial phytoplankton concentrations in the pails were as similar as possible. The pail diameter $(275 \mathrm{~mm})$ was considered large enough to avoid 'bottle effects' (Price et al. 1988). We aimed to achieve an initial concentration of chl a after dilution of between 5 and $15 \mathrm{\mu g}^{-1}$. A pilot experiment indicated that these concentrations of chl a would provide sufficient food, ensuring that approximately $40 \%$ would remain at the end of the experiment and feeding could still be detected. The chl a concentrations used were expected to remain above the critical mean concentration of $\sim 4 \mathrm{\mu g} \mathrm{l}^{-1}$ throughout the experiment and enable us to compare the ingestion rates of Nyctiphanes australis of the various phytoplankton species (McClatchie et al. 1991).

The average amount of carbon present in $\mathrm{NyC}_{\mathrm{C}}$ tiphanes australis, estimated from their average dry biomass and the carbon equivalents outlined in Parsons et al. (1984), was $1.56 \pm 0.23$ (SD) $\mathrm{mg}_{\text {animal }}{ }^{-1}$. Carbon to dry weight ratios for $N$. australis are similar to those of Euphausia pacifica (Parsons et al. 1984, James \& Wilkinson 1988).

Table 1. Taxonomic name, abbreviation and class (Andersen et al. 1997) of each of the phytoplankton used in the experiments. Taxa listed in order of increasing equivalent spherical diameter $(E S D) \pm 1 \mathrm{SD}(\mu \mathrm{m})$ of their cells

\begin{tabular}{|c|c|c|c|}
\hline Phytoplankton & Abbreviation & Class & $\mathrm{ESD} \pm \mathrm{SD}$ \\
\hline Nannochloris atomus Butcher ${ }^{\mathrm{a}}$ & $\mathrm{Na}$ & Chlorophyceae & $3.30 \pm 0.68$ \\
\hline Phaeocystis pouchetti Langerheim ${ }^{\mathrm{b}}$ & $P p$ & Prymnesiophyceae & $3.47 \pm 0.48$ \\
\hline Pavlova lutherii (Droop) Green ${ }^{a}$ & $P l$ & Prymnesiophyceae & $4.05 \pm 0.65$ \\
\hline Isochrysis galbana Parke ${ }^{a}$ & $\operatorname{Ig}$ & Prymnesiophyceae & $4.15 \pm 1.10$ \\
\hline Chaetoceros muelleri Lemmermann ${ }^{\mathrm{a}}$ & $\mathrm{Cm}$ & Bacillariophyceae & $5.37 \pm 1.19$ \\
\hline Chrysochromulina ericina Parke \& Manton ${ }^{\mathrm{b}}$ & $\mathrm{Ce}$ & Prymnesiophyceae & $5.74 \pm 1.30$ \\
\hline Pyramimonas grossi Parke ${ }^{\mathrm{b}}$ & Pyr & Prasinophyceae & $6.69 \pm 0.63$ \\
\hline Dunaliella tertiolecta Butcher ${ }^{\mathrm{a}}$ & $D t$ & Chlorophyceae & $8.10 \pm 2.15$ \\
\hline Rhodomonas lens Pascher et Ruttner ${ }^{\mathrm{a}}$ & $R l$ & Cryptophyceae & $8.97 \pm 0.72$ \\
\hline Pseudopedinella pyreforme N. Carter ${ }^{\mathrm{b}}$ & Pse & Dictyochophyceae & $9.21 \pm 0.73$ \\
\hline Tetraselmis chui Butcher ${ }^{\mathrm{a}}$ & $T C$ & Prasinophyceae & $10.47 \pm 0.53$ \\
\hline Alexandrium minutum Halim ${ }^{\mathrm{a}}$ & $A m$ & Dinophyceae & $16.95 \pm 1.58$ \\
\hline Thalassiosira sp. Cleve ${ }^{\mathrm{c}}$ & Thal & Bacillariophyceae & $25.98 \pm 5.90$ \\
\hline \multicolumn{4}{|c|}{$\begin{array}{l}{ }^{\text {a }} \text { Portobello Marine Laboratory, University of Otago, culture collection } \\
{ }^{b} \text { Isolated from Blueskin Bay, Otago, by O. B. Bojo } \\
\text { c Isolated from Blueskin Bay, Otago, by G. J. Haywood }\end{array}$} \\
\hline
\end{tabular}


Cell concentration. The contents of the pails were always stirred before they were sampled to ensure a uniform distribution of particles. More frequent sampling might have unduly disturbed the animals. Aliquots $(250 \mathrm{ml})$ were taken from each of the 3 'control' pails at the start of the experiment and from all 10 containers after 48 or $72 \mathrm{~h}$. Cells were counted by an Elzone model 180XY particle counter and by microscope (direct counts of Lugol's preserved samples) in a $1 \mathrm{ml}$ capacity Sedgewick Rafter tray. A minimum of 200 cells was counted to validate the Elzone counter.

Nyctiphanes australis. Adult $N$. australis (16 to $18 \mathrm{~mm}$ in length) were collected from $10 \mathrm{~km}$ offshore and transported to the laboratory in $20 \mathrm{l}$ pails. Healthy animals were maintained in the laboratory, 20 per pail, at $12^{\circ} \mathrm{C}$, under a $14: 10 \mathrm{~h}$ light:dark regime and a diet of Thalassiosira sp.

For the experiments, 5 animals were transferred to each pail using a scoop net to avoid the addition of extra water or food. A small aerator in every pail circulated the water. Experiments were carried out at $12^{\circ} \mathrm{C}$, the same temperature as the source of the animals, in a controlled temperature facility and in total darkness to minimise phytoplankton growth. Experiments started and ended in the afternoon and lasted for 48 or $72 \mathrm{~h}$.

Feeding rate calculations. Grazing coefficients, clearance rates and ingestion rates of Nyctiphanes australis were calculated according to Marin et al. (1986, 1987; see their Table 7). Based on these recommendations, initial concentration rather than mean concentration was used in the calculation of ingestion rates. Ingestion rates, clearance rates, cell concentrations and volumes were analysed using the Systat 5 software package (Wilkinson 1989). The acceptance level used throughout was $95 \%(\mathrm{p} \leq 0.05)$.

\section{RESULTS}

\section{Cells}

The ESD frequencies of the various phytoplankton taxa were normally distributed about mean values ranging from 3 (Nannochloris atomus) to $27 \mu \mathrm{m}$ (Thalassiosira sp.) (Table 1).

Initial cell concentrations varied among phytoplankton taxa by up to 2 orders of magnitude, as more small cells than large cells were required to obtain a chl $a$ concentration in the range 5 to $15 \mu \mathrm{g} \mathrm{l}^{-1}$. An average percentage of $51.7 \pm 6.1$ (SD) of the cells (compared to the cell concentration of the controls) remained at the end of the experiments. Nyctiphanes australis cleared more Thalassiosira sp. cells than expected, however, so that only $22 \%$ remained at the end of the experiment.

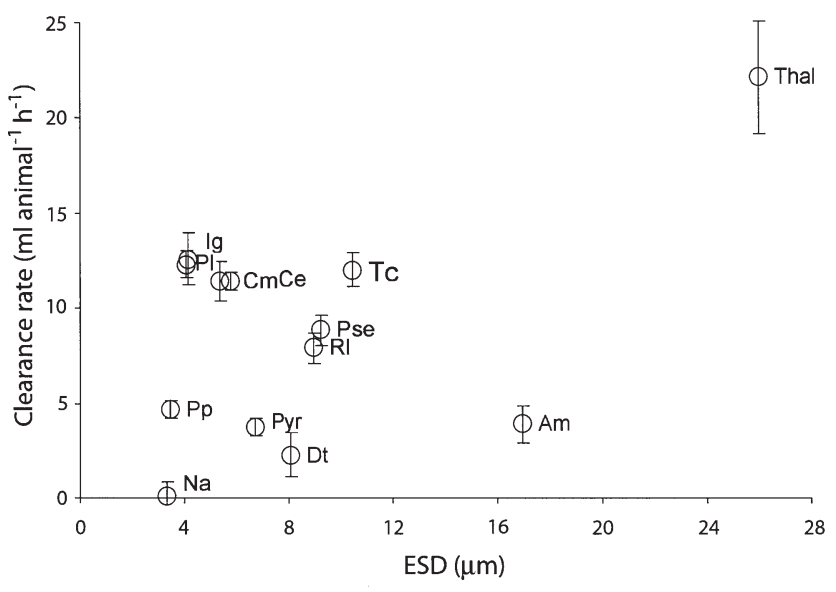

Fig. 1. Nyctiphanes australis. Clearance rates $( \pm \mathrm{SE})$ of phytoplankton cells plotted as a function of the cell ESD $(\mu \mathrm{m})$ of the taxa used (see Table 1 for abbreviations). Order $X$-axis: $N a_{\text {, }}$ $P p, P l, I g, C m, C e, P y r, D t, R l, P s e, T c, A m$, Thal

For 2 phytoplankton taxa (Nannochloris atomus and Dunaliella tertiolecta), the cell concentrations in treatments exposed to Nyctiphanes australis were not significantly different from the controls. At the end of $72 \mathrm{~h}$ exposure to Alexandrium minutum, $40 \%$ of the $N$. australis were dead or dying.

Cell clearance rates by Nyctiphanes australis ranged from $0.13 \mathrm{ml}_{\text {animal }}{ }^{-1} \mathrm{~h}^{-1}$ (Nannochloris atomus) to $22.03 \mathrm{ml}$ animal $^{-1} \mathrm{~h}^{-1}$ (Thalassiosira $\mathrm{sp}$.) and were not related linearly to the cell concentration (regression $F=2.35, \mathrm{p}=0.153$ ), or to the size of the cell (regression $F=3.71, p=0.081$ : Fig. 1, Tables $1 \& 2$ ).

Ingestion rates of cells were not directly related linearly to cell concentration (regression $F=0.50$, $\mathrm{p}=0.496)$ or the size of phytoplankton cells $(F=3.65$, $\mathrm{p}=0.083$; Table 2, Fig. 2). If Thalassiosira sp. (microplankton) is excluded, ingestion rates are related to cell size $(F=5.81, \mathrm{p}=0.037)$.

Nyctiphanes australis ingested more cells $<8 \mu \mathrm{m}$ ESD than cells $>8 \mu \mathrm{m}$ ESD $\left(t\right.$-test, $t_{2}$ tail $=2.699$, $\mathrm{p}=0.021 ;$ Table 2).

\section{Carbon}

The rate of carbon ingested was independent of the concentration of phytoplankton carbon in the pails $(F=$ $0.95, \mathrm{p}=0.351 ;$ Fig. 3$)$ and the size of the cells $(F=4.23$, $\mathrm{p}=0.064 ;$ Fig. 3). Carbon ingested by Nyctiphanes australis ranged from $0.08 \mu \mathrm{g} \mathrm{C}$ animal ${ }^{-1} \mathrm{~h}^{-1}$ (Nannochloris atomus) to $6.31 \mathrm{\mu g} \mathrm{C}$ animal ${ }^{-1} \mathrm{~h}^{-1}$ (Thalassiosira sp.), or between $0.13 \%$ (N. atomus) and $9.69 \%$ (Thalassiosira sp.) of $N$. australis' body carbon per day (Fig. 4, Table 2). There was no difference between the ingestion rate $\left(\mu \mathrm{g} \mathrm{C}\right.$ animal $\left.{ }^{-1} \mathrm{~h}^{-1}\right)$ of cells $<8 \mu \mathrm{m}$ or $>8 \mu \mathrm{m}$ ESD $\left(t\right.$-test $t_{2}$ tail $\left.=1.315, \mathrm{p}=0.192\right)$. 
Table 2. Carbon content (pg cell $\left.{ }^{-1}\right)$, concentrations $\left(\mathrm{mg} \mathrm{C} \mathrm{l}^{-1}\right)$, clearance $\left(\mathrm{ml}\right.$ animal $\left.{ }^{-1} \mathrm{~h}^{-1}\right)$ and ingestion rates $\left(10^{3}\right.$ cells $\pm \mathrm{SE}$ animal $^{-1} \mathrm{~h}^{-1}$, $\mu \mathrm{g} \mathrm{C}$ animal ${ }^{-1} \mathrm{~h}^{-1}$ ) of adult Nyctiphanes australis for the phytoplankton taxa (see Table 1 for abbreviations.) For standard errors (SE) of most rates, see Figs. 1-4. Calculations based on cell concentrations measured by electronic particle counter. $C_{0}=$ initial concentration, $C_{\mathrm{tc}}=$ concentration at time $t$ in control container, $C_{\mathrm{t}}=$ concentration at time $t$ in experimental container, $\mathrm{CR}=$ clearance rate, $\mathrm{I}=$ ingestion rate (Marin et al. 1986, 1987), \% (\% body carbon $\mathrm{d}^{-1}$ ) = carbon ingested:krill body carbon, $^{*}=$ concentrations of Nannochloris atomus and Dunaliella tertiolecta in treatments with and without euphausiids, which did not differ significantly

\begin{tabular}{|c|c|c|c|c|c|c|c|c|}
\hline & Carbon & $C_{0}$ & $C_{t \mathrm{c}}$ & $C_{t}$ & CR & I (cells) & $\mathrm{I}(\mathrm{C})$ & I (\%) \\
\hline $\mathrm{Na}$ & 4.40 & 0.649 & 0.736 & $0.730^{*}$ & 0.13 & $18.5 \pm 21$ & 0.08 & 0.13 \\
\hline$P p$ & 5.02 & 0.293 & 0.163 & 0.113 & 4.70 & $274 \pm 26$ & 1.38 & 2.11 \\
\hline$P l$ & 7.50 & 0.315 & 0.294 & 0.110 & 12.56 & $528 \pm 57$ & 3.96 & 6.08 \\
\hline$I g$ & 7.99 & 0.207 & 0.184 & 0.061 & 12.31 & $367 \pm 20$ & 2.93 & 4.50 \\
\hline $\mathrm{Cm}$ & 10.59 & 0.189 & 0.158 & 0.063 & 11.44 & $204 \pm 19$ & 2.16 & 3.31 \\
\hline $\mathrm{Ce}$ & 18.55 & 0.241 & 0.216 & 0.091 & 11.42 & $148 \pm 6.2$ & 2.75 & 4.22 \\
\hline Pyr & 27.61 & 0.173 & 0.077 & 0.045 & 3.75 & $23.4 \pm 3.1$ & 0.65 & 0.99 \\
\hline$D t$ & 44.08 & 0.376 & 0.352 & $0.293^{*}$ & 2.27 & $19.4 \pm 11$ & 0.85 & 1.31 \\
\hline$R l$ & 59.16 & 0.352 & 0.162 & 0.069 & 7.93 & $47 \pm 4.9$ & 2.79 & 4.28 \\
\hline Pse & 63.36 & 0.077 & 0.056 & 0.028 & 8.87 & $10.7 \pm 0.1$ & 0.68 & 1.04 \\
\hline$T C$ & 88.4 & 0.175 & 0.153 & 0.057 & 11.58 & $23.8 \pm 1.8$ & 2.02 & 3.11 \\
\hline$A m$ & 309.05 & 0.270 & 0.168 & 0.108 & 3.90 & $3.4 \pm 0.8$ & 1.05 & 1.62 \\
\hline Thal & 381.85 & 0.285 & 0.326 & 0.066 & 22.03 & $16.5 \pm 0.4$ & 6.31 & 9.69 \\
\hline
\end{tabular}

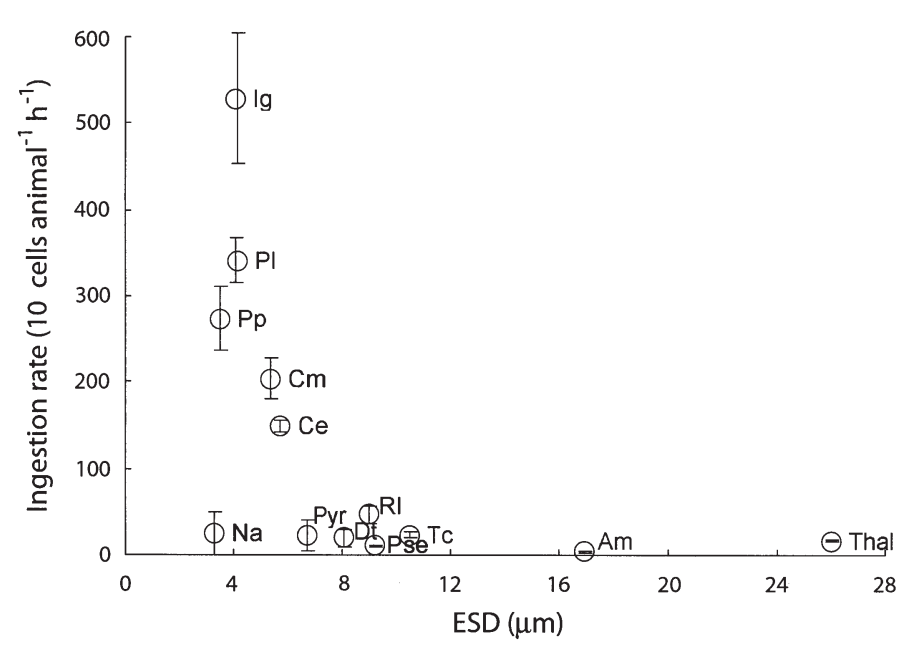

Fig. 2. Nyctiphanes australis. Ingestion rate (cells animal ${ }^{-1} \mathrm{~h}^{-1}$ $\pm \mathrm{SE})$ plotted as a function of the ESD $(\mu \mathrm{m})$ of the cells consumed (see Table 1 for abbreviations). Order $x$-axis: $N a, P p$, Pl, Ig, Cm, Ce, Pyr, Dt, Rl, Pse, Tc, Am, Thal

\section{DISCUSSION}

\section{Ingestion rates}

The results of these experiments establish that $\mathrm{Nyc}$ tiphanes australis can consume several taxa in the nanoplankton range of 2 to $20 \mu \mathrm{m}$. When presented with small cells (<8 $\mu$ m ESD), $N$. australis increased its ingestion rate to attain an intake of carbon comparable to that of a diet of cells $>8 \mu \mathrm{m}$.

We calculated that the average assimilation rate of Nyctiphanes australis is $40 \mu \mathrm{g} \mathrm{C} \mathrm{d}^{-1}$ or $2 \%$ body carbon

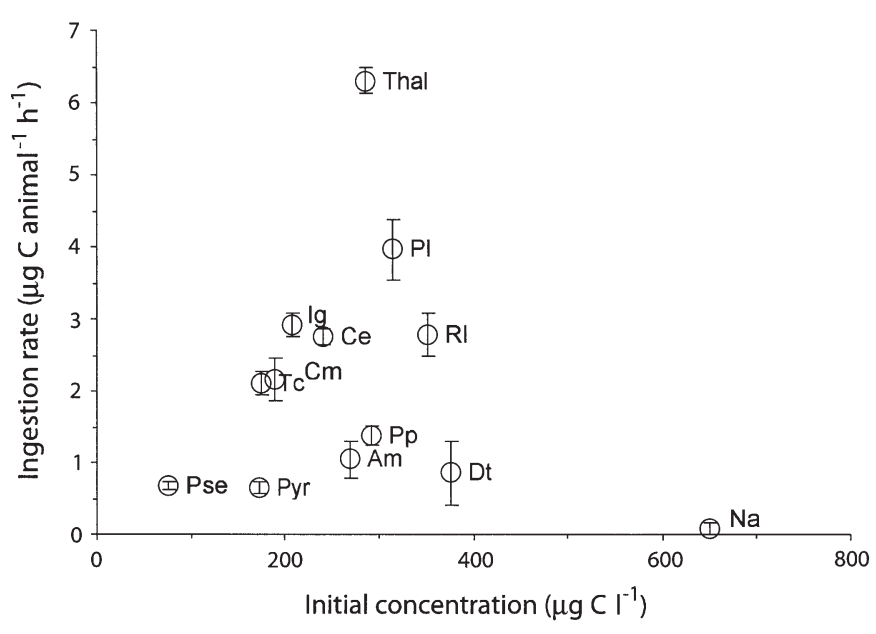

Fig. 3. Nyctiphanes australis. Ingestion rates $\left(\mu \mathrm{g} \mathrm{C}\right.$ animal ${ }^{-1}$ $\mathrm{h}^{-1} \pm \mathrm{SE}$ ) of cells plotted as a function of the initial cell concentration $\left(\mu \mathrm{C} \mathrm{C}^{-1}\right.$ ) (see Table 1 for abbreviations). Order $x$-axis: Pse, Pyr, Tc, Cm, Am, Ig, Ce, Thal, Pp, Pl, Rl, Dt, Na

$\mathrm{d}^{-1}$. This is based on the carbon budget of Ritz et al. (1990) in which $2.82 \mathrm{mg}$ of carbon was assimilated by $N$. australis for moulting and respiration during growth from 9.5 to $15 \mathrm{~mm}$ in length. This growth takes approximately 70 d (Ritz \& Hosie 1982). Boyd et al. (1984) used a similar calculation to estimate that a $45 \mathrm{~mm}$ long Euphausia pacifica requires about $100 \mu \mathrm{g} \mathrm{C} \mathrm{d} \mathrm{d}^{-1}$ or $2.3 \%$ body carbon $\mathrm{d}^{-1}$ (plus additional food for reproduction and growth) to meet its basic requirements.

Of the diets in our study, 8 provided Nyctiphanes australis with the minimum food requirement of $2 \%$ body carbon $\mathrm{d}^{-1}$ (Table 2, Fig. 4). These 8 taxa of phyto- 


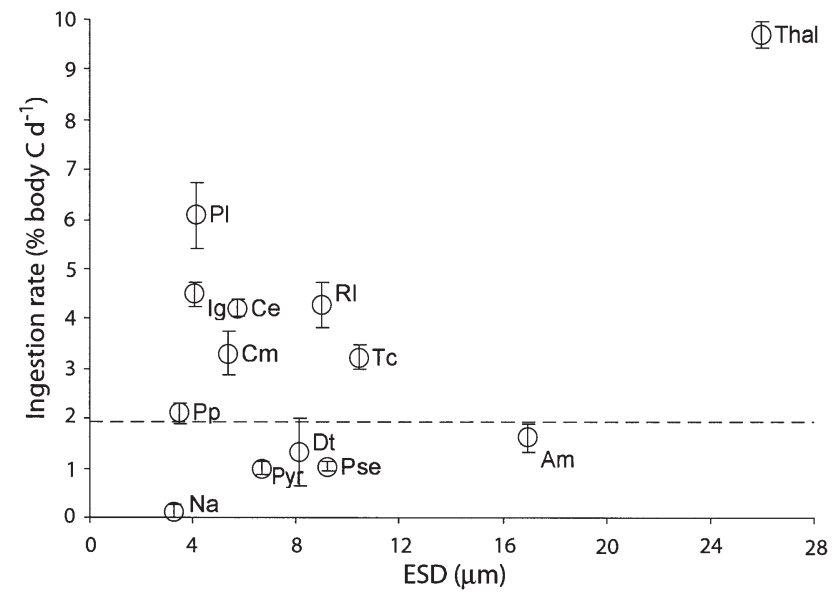

Fig. 4. Nyctiphanes australis. Ingestion rate (\% body carbon $\left.\mathrm{d}^{-1} \pm \mathrm{SE}\right)$ as a function of cell ESD $(\mu \mathrm{m})$. Dotted line represents an estimated minimum food requirement of $2 \%$ body carbon $\mathrm{d}^{-1}$ (see Table 1 for abbreviations). Order $x$-axis: $N a, P p, P I$, Ig, Cm, Ce, Pyr, Dt, Rl, Pse, Tc, Am, Thal

plankton range in cell size from 3.5 to $26 \mathrm{~mm}$ ESD. They were ingested at rates that averaged $72.3 \pm 13.0$ (SE) $\mu \mathrm{g} \mathrm{C}$ animal $\mathrm{d}^{-1}$, which is consistent with the daily carbon requirement of $73.6 \mu \mathrm{g} \mathrm{d}^{-1}$ estimated by Ritz et al. (1990). Atkinson \& Snyder (1997) report a positive relationship between carbon availability and ration for Euphausia superba, but we found no such relationship for $N$. australis within a range of approximately 75 to $750 \mu \mathrm{g} \mathrm{C} \mathrm{l}^{-1}$ available carbon. N. australis ingested Nannochloris atomus, Pyramimonas grossi, Dunaliella tertiolecta, Pseudopedinella pyreforme and Alexandrium minutum at lower rates than were necessary to satisfy minimum daily food requirements.

Nyctiphanes australis ingested the dinoflagellate Alexandrium minutum cells at the low rate of $3.4 \times$ $10^{3}$ cells animal ${ }^{-1} \mathrm{~h}^{-1}$ or $25.3 \mu \mathrm{g} \mathrm{C}$ animal ${ }^{-1} \mathrm{~d}^{-1}$, not sufficient for the minimum daily carbon requirement for $N$. australis. As the stomach contents of $N$. australis periodically contain numerous dinoflagellates (G. J. Haywood pers. obs.), we expected $A$. minutum to be ingested at high rates. A. minutum produces paralytic shellfish poison (Hallegraeff et al. 1995) and the poor survival rate of animals exposed to $A$. minutum in our study suggests that $N$. australis may be susceptible to the toxin. However, we did not expect $A$. minutum to be ingested at a low rate by $N$. australis because the euphausiid Thysanoessa raschii ingested toxic clones of Gonyaulax tamarensis (Alexandrium tamarense) at the same rate as non-toxic clones, the only difference between clones being a 'fluctuation' in the clearance rate of the toxic species (McClatchie 1988). Since ingestion of $A$. minutum by $N$. australis in our study was minimal and some animals survived, it is possible that they might be able to detect and avoid eating the toxin-bearing cells.
The presence of Nyctiphanes australis did not cause a significant change in the number of Nannochloris atomus cells and we have no evidence that $N$. australis ate $N$. atomus (Figs. 1-4). Possible explanations for the euphausiid's failure to ingest this alga are that the spacing of the setae and setules on the food-gathering limbs (pereiopods) of $N$. australis $(\sim 7 \mu \mathrm{m}$, Fig. $1 \mathrm{~A}, \mathrm{~B}$; Dalley \& McClatchie 1989) might be too wide to retain $N$. atomus, or that $N$. atomus might have chemical or physical properties that cause it to be an unpalatable food, or that $N$. australis was not motivated to eat.

The size and frequency distribution of Phaeocystis pouchetti, which is ingested, overlap with those of Nannochloris atomus, which is not ingested (Table 1), so there is no evidence that cell size alone determined why $N$. atomus was not ingested.

Dunaliella tertiolecta was poorly ingested by Nyctiphanes australis and Euphausia superba (Lasker 1966). Poor growth and survival of crustaceans (a copepod and the larvae of a brachyuran crab) on chlorophytes such as D. tertiolecta and Nannochloris atomus (Koski et al. 1998, Lehto et al. 1998) have been attributed to a deficiency of some of the essential polyunsaturated fatty acids (Støttrup \& Jensen 1990, Brown et al. 1997) or sterols (Klein Breteler et al. 1999). An alternative proposition is that chlorophytes are unpalatable, indigestible, or insufficiently nutritious to be eaten (Anderson 1978, Sarokin \& Carpenter 1982, Porra 1990, Hart 1994, Caers et al. 1998, Koski et al. 1998, Lehto et al. 1998). We conclude that some inadequacy or unpleasant attribute of the chlorophyte cells deterred N. australis from eating them.

Pyramimonas grossi and Pseudopedinella pyreforme concentrations may have fallen below the critical concentration during the experiments (Boyd et al. 1984), or there may be some unpleasant property of these cells which accounts for their low ingestion rate by $N$. australis.

\section{Clearance rates}

Ritz et al. (1990) estimated a 'filtering rate' of $6.76 \mathrm{ml}$ animal $^{-1} \mathrm{~h}^{-1}$ from the stomach fluorescence of adult Nyctiphanes australis collected in Storm Bay, Tasmania. This rate falls in the range of clearance rates of $8.73 \pm 5.75(\mathrm{SD}) \mathrm{ml}$ animal ${ }^{-1} \mathrm{~h}^{-1}$ that we measured for 13 taxa of phytoplankton and supports our conclusion that the feeding behaviour of $N$. australis in our study was similar to that in its natural environment.

Chaetoceros muelleri is sufficiently similar in size and morphology to C. gracilis for the clearance rates of these 2 species by Nyctiphanes australis to be compared. $N$. australis cleared $C$. muelleri in our study at $11.4 \pm 1.1$ (SE) $\mathrm{ml}$ animal ${ }^{-1} \mathrm{~h}^{-1}$, which is close to a rate 
of 8 to $12 \mathrm{ml}_{\text {animal }}{ }^{-1} \mathrm{~h}^{-1}$ for C. gracilis (McClatchie et al. 1991). Both species of Chaetoceros have setae that are presumed to make them easier to handle and ingest than other taxa. However, the ESD of C. muelleri and that of non-setose Chrysochromulina ericina are similar (Table 1) as are their clearance and ingestion rates by $N$. australis (Table 2), suggesting that setae per se did not make a difference.

Studies of feeding by calanoid copepods on protozoa have indicated linear relationships between clearance rates and cell size, although escape behaviours of some protozoa are also important (Burns \& Gilbert 1993). The rates at which Platymonas subcordiformis (now Tetraselmis subcordiformis), Gonyaulax polyhedra (Lingulodinium polyhedra), Thalassiosira fluviatilis (Thalassiosira weissflogii) and Dunaliella tertiolecta were cleared by Euphausia superba (mean clearance rates: $25,14.6,4.1,2.4 \mathrm{ml}$ animal ${ }^{-1} \mathrm{~h}^{-1}$; diameters: $10-15,30-45,10-20,5-10 \mu \mathrm{m}$, respectively) were not related to size (Lasker 1966). However, the clearance rates of Euphausia superba for cells $<20 \mu \mathrm{m}$ were significantly lower than those for larger cells (Meyer \& El-Sayed 1983) and clearance rates of 3 species of diatom and a prymnesiophyte (cell sizes 4 to $40 \mu \mathrm{m}$ ESD) were related to cell size (Quetin \& Ross 1985). For the 12 species of nanoplankton in our study, excluding Thalassiosira sp., clearance rates of Nyctiphanes australis were not related to taxa cell size $(F=0.14, \mathrm{p}=$ 0.716). However, the rate at which $N$. australis cleared Thalassiosira sp. (microplankton) was greater than the rate at which it cleared nanoplankton and is consistent with the findings of Meyer \& El-Sayed (1983).

Ingestion of phytoplankton by euphausiids is influenced by phytoplankton species and concentration, water temperature and euphausiid size (McClatchie 1986, 1988, Price et al. 1988, McClatchie et al. 1991, Stuart \& Huggett 1992). The mean daily ration of carbon ingested by Nyctiphanes australis exposed to 13 different taxa was $3.24 \%$ (range 0.13 to $9.69 \%$ ) body carbon. This percentage and range of carbon is similar to estimates of 0.15 to $9 \%$ body carbon $d^{-1}$ for Euphausia superba (Boyd et al. 1984, Pakhomov et al. 1997, Perissinotto et al. 1997). In our study, the carbon derived by $N$. australis from the diatom Thalassiosira sp. $\left(9.69 \pm 0.26[\mathrm{SE}] \%\right.$ body carbon $\left.\mathrm{d}^{-1}\right)$ was substantially greater than the carbon derived from any of the 12 nanoplankton taxa (mean $2.70 \pm 0.51$ [SE] \% body carbon $\mathrm{d}^{-1}$ ). The low percentage carbon derived from nanoplankton $(\leq 6 \%)$ implies that whereas diets of mixed nanoplankton would supply sufficient energy to maintain a population of $N$. australis of 9.5 to $15 \mathrm{~mm}$ length, microplankton would be necessary in the diet for reproduction to occur.

Nyctiphanes australis consumed more small cells than large cells in the range 2 to $20 \mu \mathrm{m}$, to ingest approximately the same amount of carbon (Fig. 4). This result suggests that $N$. australis adjusts its consumption of small cells to achieve the same food intake as it does on diets of larger cells. The process by which euphausiids collect food items from the water to form a bolus in their food basket (Mauchline 1980, Antezana et al. 1982, Hamner 1988, G. J. Haywood pers. obs.) may account for the higher rates of ingestion of small cells and clearance rates that are not related to cell size. Bolus size, rather than the functional size (presence of setae) or shape of the cells being consumed, may determine the rate of food intake. It is possible that electrostatic charge on cell surfaces may assist euphausiids to harvest cells $\sim 4$ m ESD (Kils 1983, Campbell et al. 1997, Hammer et al. 1999), or that sticky transparent exopolymer particles (TEP) (Alldredge et al. 1993) exuded by phytoplankton may assist euphausiids by aggregating nanoplankton-sized particles into clusters (Passow \& Alldredge 1999).

In summary, Nyctiphanes australis was not restricted to ingesting phytoplankton $>8 \mu \mathrm{m}$ ESD. Ingestion rates indicate that $N$. australis is well adapted to feeding on food in the 3.5 to $8 \mu \mathrm{m}$ ESD size range and would survive, but may not grow well or reproduce on a diet of nanoplankton.

Some phytoplankton taxa are not eaten by $\mathrm{Nyc}$ tiphanes australis for reasons other than cell size. Since $N$. australis feed discriminately and can clearly handle small cells efficiently, it is plausible that they contributed to the dominance of cells $<8 \mu \mathrm{m}$ ESD off the Otago coast in the summer of 1997-98, by selectively grazing palatable species of phytoplankton.

Acknowledgements. This work was supported by a University of Otago Postgraduate Scholarship to G.J.H We thank the reviewers for comments which greatly improved the manuscript.

\section{LITERATURE CITED}

Alldredge AL, Passow U, Logan BE (1993) The abundance and significance of a class of large, transparent organic particles in the ocean. Deep-Sea Res I 40:1131-1140

Andersen RA, Morton SL, Sexton JP (1997) Provasoli-Guillard National Center for Culture of Marine Phytoplankton Catalog of Strains. J Phycol 33(Suppl):1-75

Anderson OR (1978) Light and electron microscopic observations of feeding behavior, nutrition and reproduction in laboratory cultures of Thalassicolla nucleata. Tissue Cell 10:401-412

Antezana T, Ray K, Melo C (1982) Trophic behaviour of Euphausia superba Dana in laboratory conditions. Polar Biol 1:77-82

Atkinson A, Snyder R (1997) Krill-copepod interactions at South Georgia, Antarctica, I. Omnivory by Euphausia superba. Mar Ecol Prog Ser 160:63-76

Boyd CM, Heyraud M, Boyd CN (1984) Feeding of the Antarctic krill Euphausia superba. J Crustac Biol 4: $123-141$ 
Brewin BL (1952) Seasonal changes in micro-plankton in the Otago Harbour during the years 1944 and 1945. Trans R Soc NZ 79:614-627

Brown MR, Jeffrey SW, Volkman JK, Dunstan GA (1997) Nutritional properties of microalgae for mariculture. Aquaculture 151:315-331

Burns CW, Gilbert JJ (1993) Predation on ciliates by freshwater calanoid copepods: rates of predation and relative vulnerabilities of prey. Freshw Biol 30:377-393

Caers M, Coutteau P, Lombeida P, Sorgeloos P (1998) The effect of lipid supplementation on growth and fatty acid composition of Tapes philippinarum spat. Aquaculture 162:287-299

Campbell PGC, Twiss MR, Wilkinson KJ (1997) Accumulation of natural organic matter on the surfaces of living cells: implications for the interaction of toxic solutes with aquatic biota. Can J Fish Aquat Sci 54:2543-2554

Dalley DD, McClatchie S (1989) Functional feeding morphology of the euphausiid Nyctiphanes australis. Mar Biol 101:195-203

Dalley DE (1989) Larval development of feeding appendages and functional feeding morphology of the euphausiid, Nyctiphanes australis (GO Sars 1883). MSc thesis, University of Otago

Guillard RRL (1975) Culture of phytoplankton for feeding marine invertebrates. In: Smith WL, Chanley MH (eds) Culture of marine invertebrate animals. Plenum Press, New York, p 29-60

Guillard RRL, Ryther JH (1962) Studies of marine planktonic diatoms. I. Cyclotella nana Hustedt and Detonula confervacea Cleve. Can J Microbiol 8:229-239

Hallegraeff GM, Anderson DM, Cembella AD (eds) (1995) Manual on harmful marine microalgae. IOC Manuals \& Guides 33, UNESCO, Paris

Hammer A, Gruttner C, Schumann R (1999) The effect of electrostatic charge of food particles on capture efficiency by Oxyrrhis marina Dujardin (Dinoflagellate). Protist 150: 375-382

Hamner WM (1988) Biomechanics of filter feeding in the Antarctic krill Euphausia superba: review of past work and new observations. J Crustac Biol 8:149-163

Hardy AC (1956) The open sea - its natural history: the world of plankton. Collins, London

Hart RC (1994) Nutritional suitability of some uni-algal diets for freshwater calanoids: unexpected inadequacies of commonly used edible greens and others. Freshw Biol 31:109-116

Hawke DJ (1989) Hydrology and near-surface nutrient distribution along the South Otago continental shelf, New Zealand, in summer and winter 1986. NZ J Mar Freshw Res 23:411-420

James MR, Wilkinson VH (1988) Biomass, carbon ingestion, and ammonia excretion by zooplankton associated with an upwelling plume in western Cook Strait, New Zealand. NZ J Mar Freshw Res 22:249-257

Jørgensen CB (1966) Biology of suspension feeding. Pergamon Press, London

Kils U (1983) Swimming and feeding of Antarctic krill, Euphausia superba-some outstanding energetics and dynamics-some unique morphological details. In: Schnack SB (ed) Berichte zur Polarforschung, Sonderheft 4. On the biology of krill Euphausia superba, proceedings of the seminar and report of the krill ecology group. Alfred Wegener Institut für Polarforschung, Bremerhaven, p 130-155

Klein Breteler WCM, Schogt N, Baas M, Schouten S, Kraay GW (1999) Trophic upgrading of food quality by proto- zoans enhancing copepod growth: role of essential lipids. Mar Biol 135:191-198

Koski M, Klein Breteler W, Schogt N (1998) Effect of food quality on rate of growth and development of the pelagic copepod Pseudocalanus elongatus (Copepoda, Calanoida). Mar Ecol Prog Ser 170:169-187

Lasker R (1966) Feeding, growth, respiration and carbon utilization of a euphausiid crustacean. J Fish Res Board Can 23:1291-1317

Lehto J, Sulkin S, Strom S, Johnson D (1998) Protists and detrital particles as prey for the first larval stage of the brachyuran crab, Hemigrapsus oregonensis. J Exp Mar Biol Ecol 230:213-224

Marchant HJ, Nash GV (1986) Electron microscopy of gut contents and faeces of Euphausia superba Dana. Mem Natl Inst Polar Res 40:167-177

Marin V, Huntley ME, Frost B (1986) Measuring feeding rates of pelagic herbivores: analysis of experimental design and methods. Mar Biol 93:49-58

Marin V, Huntley ME, Frost B (1987) Corrigendum. Mar Biol 95:156

Mauchline J (1980) The biology of the mysids and euphausiids. In: Blaxter JHS, Russell F, Yonge M (eds) Adv Mar Biol 18. Academic Press, London, p 373-623

McClatchie S (1986) Time-series feeding rates of the euphausiid Thysanoessa raschii in a temporally patchy food environment. Limnol Oceanogr 31:469-477

McClatchie S (1988) Functional response of the euphausiid Thysanoessa raschii grazing on small diatoms and toxic dinoflagellates. J Mar Res 46:631-646

McClatchie S, Boyd CM (1983) Morphological study of sieve efficiencies and mandibular surfaces in the Antarctic krill, Euphausia superba. Can J Fish Aquat Sci 40:955-967

McClatchie S, Jaquiery P, Kawachi R, Pilditch C (1991) Grazing rates of Nyctiphanes australis (Euphausiacea) in the laboratory and Otago Harbour, New Zealand, measured using three independent methods. Cont Shelf Res 11:1-22

Meyer MA, El-Sayed SZ (1983) Grazing of Euphausia superba Dana on natural phytoplankton populations. Polar Biol 1: 193-197

Opalinski KW, Maciejewska K, Georgieva LV (1997) Notes on food selection in the Antarctic krill Euphausia superba. Polar Biol 17:350-357

Pakhomov EA, Perissinotto R, Froneman PW, Miller DGM (1997) Energetics and feeding dynamics of Euphausia superba in the South Georgia region during the summer of 1994. J Plankton Res 19:399-423

Parsons TR, LeBrasseur RJ, Fulton JD (1967) Some observations on the dependence of zooplankton grazing on cell size and concentration of phytoplankton blooms. J Oceanogr Soc Jpn 23:10-17

Parsons TR, Maita Y, Lalli CM (1984) A manual of chemical and biological methods for seawater analysis. Pergamon Press, Oxford

Passow U, Alldredge AL (1999) Do transparent exopolymer particles (TEP) inhibit grazing by the euphausiid Euphausia pacifica? J Plankton Res 21:2203-2217

Perissinotto R, Pakhomov EA, McQuaid CD, Froneman PW (1997) In situ grazing rates and daily ration of Antarctic krill Euphausia superba feeding on phytoplankton at the Antarctic Polar Front and the Marginal Ice Zone. Mar Ecol Prog Ser 160:77-91

Porra RJ (1990) A simple method for extracting chlorophylls from the recalcitrant alga, Nannochloris atomus, without formation of spectroscopically-different magnesium-rhodochlorin derivatives. Biochim Biophys Acta 1019:137-141

Price HJ, Boyd KR, Boyd CM (1988) Omnivorous feeding 
behavior of the Antarctic krill Euphausia superba. Mar Biol 97:67-77

Quetin LB, Ross RM (1985) Feeding by Antarctic krill, Euphausia superba: does size matter? In: Siegfried WR, Condy PR, Laws RM (eds) Antarctic nutrient cycles and food webs. Springer-Verlag, Berlin, p 372-377

Ritz DA, Hosie GW (1982) Production of the euphausiid Nyctiphanes australis in Storm Bay, south-eastern Tasmania. Mar Biol 68:103-108

Ritz DA, Hosie GW, Kirkwood RJ (1990) Diet of Nyctiphanes australis Sars (Crustacea: Euphausiacea). Aust J Mar Freshw Res 41:365-374

Editorial responsibility: Otto Kinne (Editor),

Oldendorf/Luhe, Germany
Sarokin DJ, Carpenter EJ (1982) Ultrastructure and taxonomic observations on marine isolates of the genus Nannochloris (Chlorophyceae). Bot Mar 25:483-491

Støttrup JG, Jensen J (1990) Influence of algal diet on feeding and egg-production of the calanoid copepod Acartia tonsa Dana. J Exp Mar Biol Ecol 141:87-105

Stuart V, Huggett JA (1992) Prey selection by Euphausia lucens (Hansen) and feeding behaviour in response to a mixed algal and animal diet. J Exp Mar Biol Ecol 164: $117-133$

Wilkinson L (1989) SYSTAT: the system for statistics. SYSTAT, Evanston, IL

Submitted: November 29, 2001; Accepted: January 8, 2003 Proofs received from author(s): April 8, 2003 